\title{
Role of leukemia inhibitor factor (LIF) in decidualisation of murine uterine stromal cells in vitro
}

\author{
A A Fouladi Nashta ${ }^{1}$, C V Andreu ${ }^{1}$, N Nijjar ${ }^{1}$, J K Heath ${ }^{2}$ and \\ S J Kimber ${ }^{1}$ \\ ${ }^{1}$ School of Biological Sciences, University of Manchester, Manchester M13 9PT, UK \\ ${ }^{2}$ School of Biosciences, University of Birmingham, Birmingham B15 2TT, UK \\ (Requests for offprints should be addressed to Susan J. Kimber, School of Biological Sciences, University of Manchester, 3.239 Stopford Building, Oxford Road, \\ Manchester M13 9PT, UK; E-mail: skimber@fs1.scg.man.ac.uk) \\ (C V Andreu is currently at the Department of Biological Sciences, University of Calgary, Calgary, T2N 1N4 Canada) \\ (A A Fouladi Nashta is currently at the University of Nottingham, School of Biosciences, Nottingham LE12 5RD, UK)
}

\begin{abstract}
Decidualisation of uterine stromal cells is a prerequisite for implantation of the embryo in mice. Here we have used an in vitro culture system in which stromal cells decidualise as indicated by a number of markers, including an increase in alkaline phosphatase (ALP) activity. The latter was used as a quantitative marker of decidualisation in the presence of low (2\%) fetal calf serum. Prostaglandin $\mathrm{E}_{2}\left(\mathrm{PGE}_{2}\right)$, which is known to induce decidualisation, increased ALP activity, and this effect was blocked in a dose-dependent manner by indomethacin. Leukemia inhibitory factor (LIF) was then examined, but it had no effect on $\mathrm{PGE}_{2}$ secretion. However, LIF suppressed ALP activity in a dose-dependent manner in the presence of $2 \%$ serum, while an inhibitor of LIF that competes for binding to its receptor reversed the effect of LIF and increased ALP activity above the control level. In serum-free cultures,
\end{abstract}

stromal cells differentiated rapidly, and no differences were observed between LIF-treated and untreated cultures. Stromal cells produce LIF during in vitro culture, and this peaked at $48 \mathrm{~h}$. Freshly collected stromal cells from both day- 2 and -4 pregnant mice expressed mRNA for the LIF receptor, and the transcript level was higher in cells isolated on day 4. However, no differences were observed in the relative levels of transcripts in cells from day 2 and day 4 after culture, nor were there differences between the LIF-treated cultures and controls. Therefore, in this study, we have shown that LIF suppresses decidualisation of murine uterine stromal cells in the presence of serum, this is not due to the regulation of $\mathrm{PGE}_{2}$ secretion by stromal cells.

Journal of Endocrinology (2004) 181, 477-492

\section{Introduction}

For implantation of the mammalian embryo, sequential morphological and biochemical changes must occur in both embryo and uterus. The embryo must develop to the blastocyst stage and then hatch prior to attachment to the uterine luminal epithelium. The uterus, in turn, must undergo a differentiation process which makes it receptive, allowing attachment and implantation of the embryo. Following dialogue between the implanting embryo and the endometrium at the implantation site, the embryo can adhere to the luminal surface of the lining epithelium and implant into the uterus. The changes in the uterus are regulated by ovarian steroids and occur both in the luminal epithelium and the underlying stromal cells. Fibroblastic cells of the latter undergo extensive proliferation and then differentiation, a process referred to as decidualisation (Gambel et al. 1985, Weitlauf \& Suda-Hartman 1988, Abrahamsohn \& Zorn 1993, Zhang
\& Croy 1996, Kurita et al. 2001). Decidualisation involves uterine stromal cell differentiation and remodelling of the extracellular matrix, as well as a remarkable change in the population and distribution of leukocytes in the uterus. Decidualised stromal cells change their shape from fibroblastic to large, polyploid and multinucleated cells (Ansell et al. 1974, Monice et al. 2001). Among the most obvious modifications during decidualisation is the increase in alkaline phosphatase (ALP) enzyme activity (Finn \& McLaren 1967, Pollard et al. 1990) and vascular permeability (Psychoyos 1993). In mice and rats, the content of active ALP increases in the antimesometrial decidualised stromal cells at the time of implantation and then spreads through the stromal layer during pregnancy (Murdoch et al. 1978, Johansson \& Wide 1994). ALP has frequently been used as a marker of stromal cell decidualisation in vitro in the rat (Kennedy et al. 1998). Decidual cells also express the intermediate filament protein desmin, which appears first in the primary decidual zone, and then progresses 
laterally to the mesometrial stromal cells (Glasser et al. 1987). In addition, there are changes in oligosaccharide expression - for instance, in the distribution of sialylated structures, such as $\alpha 2-6$ sialyl residues recognised by lectin SNA (Jones et al. 1996), and stage-specific antigen-3 (SSEA-3) (Gendron et al. 1997). More recently, many other molecular changes have also been documented, as in transcription factor HoxA-10 (Benson et al. 1996) and various signalling molecules (Ying \& Zhao 2000, Paria et al. 2001).

Several factors have been shown to be capable of acting as inducers or essential factors for decidualisation, including infusion of oil and polysaccharides into the uterine lumen (Finn 1966), steroids (Pollard et al. 1990), prostaglandins (PGs) (Kennedy \& Doktorcik 1988), platelet activating factor (PAF) (O’Neill 1985), leukotrienes (Kennedy \& Doktorcik 1988), transforming growth factor (TGF)- $\alpha$ (Pollard et al. 1990), leukemia inhibitory factor (LIF) (Stewart et al. 1992, Chen et al. 2000) and heparinbinding epidermal growth factor (HB-EGF) (Paria et al. 2001). Although a plethora of molecules have been implicated in implantation and decidualisation, most appear not to be essential, as shown by gene deletion in mice. However, maternal expression of both PGs and LIF appears vital for timely and successful implantation of the murine embryo. The levels of PGs and prostacyclins (particularly $\mathrm{PGE}_{2}$ and $\mathrm{PGI}_{2}$ ) increase in implantation sites compared with the pre-implantation uterus or interimplantation site (Bany et al. 1998, Ushikubi et al. 1998, Bany \& Kennedy 1999). In addition, local administration of PGs induces decidualisation (Sananes et al. 1976, Kennedy 1986), and the use of drugs that inhibit PG synthesis (such as indomethacin (IM)) averts or delays decidualisation (Evans et al. 1982). PGs are produced from arachidonic acid by the rate-limiting cyclooxygenase (COX) enzymes. In most species, COX-2 is restricted to the implantation site, where it is expressed in luminal epithelium and stromal cells surrounding the active blastocyst during attachment (Chakraborty et al. 1996, Lim et al. 1999). Indeed, COX-2-deficient mice exhibit multiple reproductive failures, including defects in ovulation and fertilisation, and reduced or delayed decidualisation (Reese et al. 1999, Cheng et al. 2002).

LIF is a pleiotrophic member of the interleukin 6 (IL-6) cytokine family (Pennica et al. 1995, Haines et al. 2000). The expression of LIF mRNA and protein peaks first during ovulation and then on day 4 of pregnancy prior to embryo attachment (Bhatt et al. 1991, Shen \& Leder 2000). LIF acts on its target cells by binding to a low-affinity receptor (LIF-R $\beta$ ) which dimerises with gp130, a protein common to the receptors for other members of the IL-6 family, thus transforming to a high-affinity form for signal transduction (Gearing et al. 1992, Song et al. 2000). In LIF-null mice, the uterus does not decidualise and blastocysts fail to implant. However, pregnancies do result in $\mathrm{LIF}^{-/-}$mothers after infusion or injection of exogenous LIF, and LIF $^{-/-}$embryos can implant after transfer into wild-type pseudopregnant recipient uteri (Stewart et al. 1992, Chen et al. 2000). Furthermore, by in situ hybridisation, it has recently been shown that COX-2 mRNA is aberrantly expressed in $\mathrm{LIF}^{-/}$mice during implantation (Song et al. 2000). The molecular mechanism by which LIF exerts its effect and regulates the implantation process and its interaction with other factors involved in decidualisation and implantation has yet to be clarified.

Uterine stromal cells have been isolated and cultured successfully in a number of species (Glasser \& McCormack 1979, Satyaswaroop et al. 1979, Siegfried et al. 1984, Inaba et al. 1988, Arnold et al. 2001). With a well-defined culture system, it is possible to understand the characteristics and physiological capabilities of primary cells and their interaction. In the present study, isolated cultured stromal cells underwent decidualisation as assessed morphologically and from immunohistochemical staining for decidual markers and quantitative measurement of ALP activity. The main target for LIF in its regulation of implantation has been suggested to be the luminal epithelium (Chen et al. 2000). However, the direct effect of LIF on stromal cells has not been examined. We hypothesised that LIF might directly stimulate decidualisation in stromal cells rather than indirectly via signals from the luminal epithelium. Therefore, the effect of LIF and $\mathrm{PGE}_{2}$ and their inhibitors on murine stromal cells was examined with ALP as a quantitative measure of decidualisation. Contrary to our expectation, we found that LIF had an inhibitory effect on decidual differentiation as measured by ALP activity, and that this was not the result of suppression of $\mathrm{PGE}_{2}$ secretion.

\section{Materials and Methods}

\section{Animals}

Three-week-old MF1 female mice (Harlan Olac, Bicester, UK) were maintained under a controlled photoperiod of 12-h light:12-h dark with food and water supplied ad libitum. The mice were induced to ovulate by an intraperitoneal injection of a single dose of 5 IU PMSG (Intervet, Milton Keynes, UK) followed by a single injection of 5 IU HCG (Intervet) $48 \mathrm{~h}$ later. Mating was confirmed by the observation of a vaginal plug the following morning (day 1 of pregnancy). The animals were killed by cervical dislocation on either day 2 of pregnancy (48 $\mathrm{h}$ after HCG injection) or on day 4 . The uterine horns were dissected and trimmed of excess fat and mesentery tissues before transfer into Hanks' balanced salt solution (HBSS; Invitrogen, Paisley, UK).

\section{Chemicals}

All of the chemicals were from Sigma (Poole, UK) unless otherwise stated. Primary antibodies and lectins were as 
follows: polyclonal rabbit antimouse desmin (1:100), monoclonal rat antimouse SSEA-3 (Hybridoma bank; 1:20), mouse monoclonal immunoglobulin (Ig) M HOO1 (from Dr A Lundblad, University of Lund, Sweden) (Kimber et al. 1988) and digoxigenin-labelled Sambuccus nigra lectin (SNA: Boehringer Mannheim, Germany; 1:50). Fluorescein isothiocyanate (FITC)-conjugated antirat or rabbit IgGs (Jackson Labs, Pennsylvania, PA, USA) were used as secondary antibodies at a dilution of 1 in 125 . FITC-labelled antidigoxigenin (Boehringer) was used at a dilution of 1:250. Normal goat serum (NGS) was used at a dilution of 1:20 for blocking non-specific binding.

Mouse LIF used as the standard in ELISA was purchased from Chemicon (Chandlers Ford, Hants, UK), and LIF used in culture was a gift from Dr Ann Vernallis (Aston University, Birmingham, UK), and its activity was calibrated by the proliferation response of BAF cells (gift of Dr Ann Vernallis). The LIF inhibitor (LIF 05) that antagonises LIF activation of its receptor was reported previously (Vernallis et al. 1997) and used at 10 times the added LIF concentration, or $50 \mathrm{ng} / \mathrm{ml}$, in the absence of LIF. PGE ${ }_{2}$ and IM were diluted in culture medium from $1 \mathrm{mg} / \mathrm{ml}$ and $0.1 \mathrm{M}$ stocks (respectively) in absolute ethanol. Absolute ethanol was added at equivalent dilution to control cultures in each case.

\section{Isolation and culture of stromal cells}

Uterine stromal cells were isolated by a modification of the method established by McCormack and Glasser (1980) and cultured. Briefly, fat-trimmed uteri were cut longitudinally to expose the lumen. They were then placed in the first trypsin dissociation solution ( $0.5 \%$ type II bovine trypsin and $0 \cdot 165 \%$ pancreatin in HBSS (Invitrogen) for $1 \mathrm{~h}$ at $4{ }^{\circ} \mathrm{C}$ followed by $1 \mathrm{~h}$ at room temperature. The medium was then removed (with detached luminal epithelial plaques) and discarded, and the remaining uterine tissue washed and vortexed in ice-cold HBSS. This step was followed by two quick washes in cold HBSS containing $1 \mu \mathrm{g} / \mathrm{ml}$ DNAse, $5 \mu \mathrm{l} / \mathrm{ml}$ of $10 \mathrm{mM} \mathrm{MgCl}_{2}$ and $1 \%$ heat inactivated fetal calf serum (HIFCS) (Invitrogen) followed by rapid washing with cold HBSS. At this stage, 10 glass beads were added, together with the second trypsin dissociation solution (0.05\% trypsin and $0.02 \%$ EDTA (BDH) in HBSS). The tube was vortexed twice during a 20 -min incubation at $37^{\circ} \mathrm{C}$ and then incubated for $20 \mathrm{~min}$ at room temperature with vortexing every $5 \mathrm{~min}$. The content of the tube was then passed through a $70 \mu \mathrm{m}$ gauze filter (Falcon), and the enzymatic digestion was stopped by adding trypsin inhibitor solution $(2 \%$ soybean trypsin inhibitor in HBSS) after filtration. The cell suspension was then centrifuged at $400 \mathrm{~g}$ for $10 \mathrm{~min}$ at $4{ }^{\circ} \mathrm{C}$. The pellet was washed in stromal cell culture medium: 1:1 mixture of DMEM and Ham's F12 medium (Invitrogen) supplemented with $1.2 \mathrm{~g} / 1$ of sodium bicarbonate, $100 \mathrm{IU} / \mathrm{ml}$ penicillin streptomycin (Invitrogen) and 2\% HIFCS (Invitrogen), and centrifuged for $10 \mathrm{~min}$ at $4{ }^{\circ} \mathrm{C}$. The same batch of serum was used throughout the entire study. The pellet was resuspended in stromal cell culture medium, and live cells were assessed by trypan blue exclusion with a Neubauer haemocytometer. Isolated stromal cells were cultured in 24-well culture dishes (Nunc, Paisley, UK) at $1.5 \times 10^{5}$ cells $/ \mathrm{ml}$ in a humid atmosphere of $5 \% \mathrm{CO}_{2}$ in air at $37^{\circ} \mathrm{C}$. The culture medium was renewed after $24 \mathrm{~h}$ and then every 24 or $48 \mathrm{~h}$. Evaluation was undertaken on a minimum of three cultures in each case.

\section{Immunocytochemistry for decidual markers on cultured stromal cells}

Stromal cells were cultured on $13 \mathrm{~mm}$ sterile glass cover slips $(\mathrm{BDH})$ in 24-well culture dishes. At 24-h intervals, the culture medium was removed from the cover slips, which were quickly washed with cold PBS, fixed for 5 min in cold acetone $\left(4{ }^{\circ} \mathrm{C}\right)$ and stored at $-20^{\circ} \mathrm{C}$ until required for immunocytochemistry. This was performed with a 45-min blocking step with 1:20 normal goat serum in PBS containing 1\% BSA and $0.05 \%$ sodium azide, preceding the primary (overnight at $4{ }^{\circ} \mathrm{C}$ ) and secondary (90 $\mathrm{min}$ at room temperature) antibody. Cover slips were then washed and mounted on glass slides with Gelvatol and examined under a Leica epifluorescence microscope (Leica UK). The intensity of staining was scored and ranged from $(+++)$ for maximum to $(---)$ for no staining.

\section{Measurement of total protein concentration and alkaline phosphatase activity}

The cells were lysed in the wells in $250 \mu \mathrm{l} \quad 0 \cdot 25 \%$ deoxycholate. The lysates of three wells were pooled in Eppendorf tubes and stored at $-20{ }^{\circ} \mathrm{C}$ until use for ALP activity determination and protein assay. Samples for basal activity $(T=0)$ determination were taken before seeding. Freshly isolated cells from three wells were transferred to an Eppendorf tube and centrifuged at $400 \mathrm{~g}$ for $5 \mathrm{~min}$. The medium was then removed and the pellet resuspended in $750 \mu \mathrm{l}$ deoxycholate. Samples were processed for total protein determination by the BCA method (Pierce), with BSA (Pierce) as standard and saline deoxycholate solution (250 $\mu \mathrm{l} 0 \cdot 9 \%$ saline plus $500 \mu \mathrm{l}$ deoxycholate) as blank in a 96-well assay plate (Nunc). The colour was read with a microplate reader (Dynatech, MR500) at $570 \mathrm{~nm}$. A standard curve was plotted by using serial dilutions of BSA in saline. A volume of $200 \mu \mathrm{l}$ of BCA reagent was added to $20 \mu \mathrm{l}$ of samples and standard solutions, according to the manufacturer's instructions. The activity of ALP enzyme was assessed with the Sigma kit 204 in a 96-well assay plate with a microplate reader. The method is based on the ability of the enzyme to convert $p$-nitrophenyl phosphate to $p$-nitrophenol, which in alkaline solution presents as 
a yellow colour and can be read at $410 \mathrm{~nm}$. A standard curve was plotted by serial dilution of the standard. The concentration of ALP in each sample was measured by logarithmic conversion of optical density to absorbance ratio. The activity of ALP enzyme was expressed as ng of product/30 min per $\mathrm{mg}$ of total protein.

\section{Cell proliferation assay}

Cells were cultured as above and harvested at 24-h intervals until $96 \mathrm{~h}$ of culture. The cells were removed with warm $\left(37^{\circ} \mathrm{C}\right)$ trypsin/EDTA $((0 \cdot 05 \%$ trypsin and $1 \mathrm{mM}$ EDTA $(\mathrm{BDH}))$ at $37^{\circ} \mathrm{C}$ for $5 \mathrm{~min}$, followed by gentle pipetting and incubation for $10 \mathrm{~min}$ at room temperature. The cell suspension was placed in $300 \mu \mathrm{l}$ HBSS containing 20\% HIFCS. Cells were centrifuged and resuspended in $1 \mathrm{ml}$ of fresh HBSS. A volume of $10 \mu \mathrm{l}$ cell suspension was mixed with an equal volume of trypan blue, and live cells that excluded the dye were counted in a Neubauer chamber.

\section{PGE RIA}

The concentration of $\mathrm{PGE}_{2}$ was measured in the culture media by Sigma RIA, and standards $(0-100 \mathrm{pg} / \mathrm{ml})$ were prepared in RIA buffer $(0 \cdot 01 \mathrm{M}$ PBS, $\mathrm{pH} 7 \cdot 4$, containing $0 \cdot 1 \%$ BSA and $0 \cdot 1 \%$ sodium azide). Volumes of $100 \mu \mathrm{l}$ sample or standards and $500 \mu$ antibody working solution were added to $1.5 \mathrm{ml}$ Eppendorf tubes. These were vortexed, incubated for $30 \mathrm{~min}$ at $4{ }^{\circ} \mathrm{C}$, and then ${ }^{3} \mathrm{H}$ labelled PGE (Amersham), diluted in RIA buffer to give 6000 c.p.m. in $700 \mu \mathrm{l}$, was added. The tubes were vortexed again and incubated for $1 \mathrm{~h}$ at $4{ }^{\circ} \mathrm{C}$, and then $200 \mu \mathrm{l}$ cold dextran-coated charcoal suspension $(0 \cdot 1 \%$ dextran, 1\% activated charcoal (100-400 mesh) in RIA buffer) was added. This mixture was shaken for $10 \mathrm{~min}$ at $4{ }^{\circ} \mathrm{C}$. Finally, the tubes were centrifuged at $800 \mathrm{~g}$ for $15 \mathrm{~min}$ at $4{ }^{\circ} \mathrm{C}$, and the supernatants were transferred into scintillation vials with $4 \mathrm{ml}$ of scintillation cocktail (Optiphase Hisafe 2, Wallac). The amount of radioactivity in all tubes was measured with a beta-counter (Wallac-M1214) and the sample concentration extrapolated from the standard curve. The values were considered reliable only in the logit interval of $\pm 2 \cdot 2$ when the unlabelled molecules displace 10-90\% of maximum radioactivity bound (Granstrom \& Kindahl 1983).

\section{Isolation of total RNA}

Total RNA was isolated from both freshly collected stromal and epithelial cells on days 2 and 4 of pregnancy, as well as from stromal cells cultured between 24 and $96 \mathrm{~h}$ in the presence or absence of LIF. The latter cells were detached from the wells with a cell scraper (Corning), and the cell suspensions from 10 wells were pooled and centrifuged at $1000 \mathrm{~g}$ for $5 \mathrm{~min}$. The supernatant culture medium was removed, and the pellet was stored in liquid nitrogen. RNA was isolated from all samples with the RNeasy Mini Kit (Qiagen), according to the manufacturer's instructions. Lysis buffer was added to the cells, and the contents were repeatedly passed through 19 gauge needles, and then centrifuged through Quiashredder membranes (Qiagen) for complete lysis. The concentration of total RNA was measured with a Genequant (Amersham Bioscience, Amersham, UK) spectrophotometer.

\section{RT-PCR for the LIF receptor}

A one-step RT-PCR kit (Qiagen) was used according to the manufacturer's instructions for RT and amplification of a $350 \mathrm{bp}$ product with the primers, $5^{\prime}$ CTTCGATCC TCAACACAGAGC3' (forward) and 5'TGGTTAGTG CACCCATAGAGG3' (reverse), designed using the sequence of Mus musculus LIF receptor mRNA and the Primer 3 program (accession number: NM_013584·1). An amount of $1 \mu \mathrm{g}$ RNA was used for reverse transcription and PCR over 30 cycles with TM of $60^{\circ} \mathrm{C}$ and 5 -min extension. For experiments where LIF receptor mRNA transcripts were compared between different groups, the tubes were removed from the cycler (Eppendorf) every two cycles after cycle 18 . Extension was then continued in another machine. $\beta$-Actin primers (5'AAA CTG GAA CGG TGA AGG C3' (forward) and 5'CCT GGG CCA TTC AGA AAT TA 3' (reverse)), amplifying a 344 bp product, were used for normalisation, with the cycle number at which $\beta$-actin was first detected used to compare cDNA quantities from different samples. The set of amplification cycles used was determined to be in the linear range. A volume of $10 \mu \mathrm{l}$ product or standards (Roche) mixed with $2 \mu \mathrm{l}$ of tracking dye was loaded on a 2\% agarose (Amersham) gel (containing 2\% ethidium bromide) and run at $100 \mathrm{mAmp}$ for $1 \mathrm{~h}$ in a BioRad electrophoresis tank. For the negative control, distilled water replaced RNA. A BAF cell line (a gift from Dr Ann Vernallis) that expresses LIF receptor was used as positive control. The bands were visualised and photographed on a transilluminator connected to a Kodak camera.

\section{ELISA for LIF production by stromal cells}

Capture and detection antibodies and standards (both hLIF and mLIF) for enzyme-linked immunoassay of human LIF were purchased from R \& D Systems, Abingdon, Oxon, UK, and the ELISA was calibrated for use with murine LIF. The assay was performed according to the manufacturer's instructions on Maxisorb 96-well dishes (Nunc). Briefly, assay dishes were coated with $100 \mu \mathrm{l}$ of capture antibody $(4 \mathrm{ng} / \mathrm{ml})$ overnight at room temperature (RT) and the wells were then washed three times with PBS washing buffer. Non-specific binding was blocked with PBS containing 1\% BSA for $1 \mathrm{~h}$ at RT. The blocking 
solution was removed, and $100 \mu \mathrm{l}$ of either Microcon 100 concentrated (Centricon: Millipore, USA) culture medium or serially diluted standards were added to wells. The dish was incubated for $2 \mathrm{~h}$ at $\mathrm{RT}$ and washed again, and $100 \mu \mathrm{l}$ of detection antibody (biotinylated LIF antibody) was added to each well and incubated for $2 \mathrm{~h}$ at RT. After washing, $100 \mu \mathrm{l}$ of peroxidase-conjugated streptavidin HRP (Zymed, 1:200 in 1\% BSA in PBS) was added to each well to induce a colour reaction. The reaction was stopped by adding $50 \mu \mathrm{l}$ of $1 \mathrm{M} \mathrm{H}_{2} \mathrm{SO}_{4}$. With a plate reader (Dynatech), a logarithmic linear curve was plotted for the ratio of optical density to concentration of standards, and concentrations of LIF in the samples were read from the standard curve.

\section{Statistical analysis}

Data are presented as mean \pm S.E.M. Statistical analysis was performed with the SPSS program to carry out a two-way analysis of variance on the data. A post hoc test was then used to analyse the difference between control and treatments. Tukey's test was also used to reveal the differences between each treatment.

\section{Results}

\section{Murine stromal culture and decidualisation in vitro}

Initially, stromal cells were isolated from day 2 pregnant mice, cultured in the presence of $2 \%, 5 \%$ or $10 \%$ HIFCS for up to $96 \mathrm{~h}$, and used for assessment of decidualisation by quantitative measurement of ALP in cell lysates together with other qualitative markers. In all cases, cells with the expected appearance of fully mature decidual cells (large size, frequently binucleate, carrying processes and with a spread appearance) were detected and the frequency of these cells increased with time in culture in $2 \%$ and $5 \%$ serum. In $10 \%$ serum, the number of cells with this appearance was greatly reduced. ALP activity generally increased with time in culture up to $48-72 \mathrm{~h}$, after which it plateaued or decreased. Very low levels of ALP activity were detected in 10\% serum, confirming the low frequency of cells with a decidualised appearance (Fig. 1). To minimise the influence of serum factors, $2 \%$ HIFCS was used for the later experiments. Decidualisation of stromal cells derived from day 2 and day 4 pregnant mice was compared, using a range of markers. No differences were found between cells from these two days over the period of culture (data not shown). Therefore, stromal cells isolated from day 2 of pregnancy were used for the remainder of the work. Binucleate and giant cells were detected even at $24 \mathrm{~h}$, but these increased at 48 and $72 \mathrm{~h}$ of culture (Fig. 2). The results of immunocytochemistry for the decidual markers desmin, ALP, SSEA-3 and SNA are shown in Fig. 2 and summarised in Table 1. Cells stained for decidual markers even after $24 \mathrm{~h}$, but staining

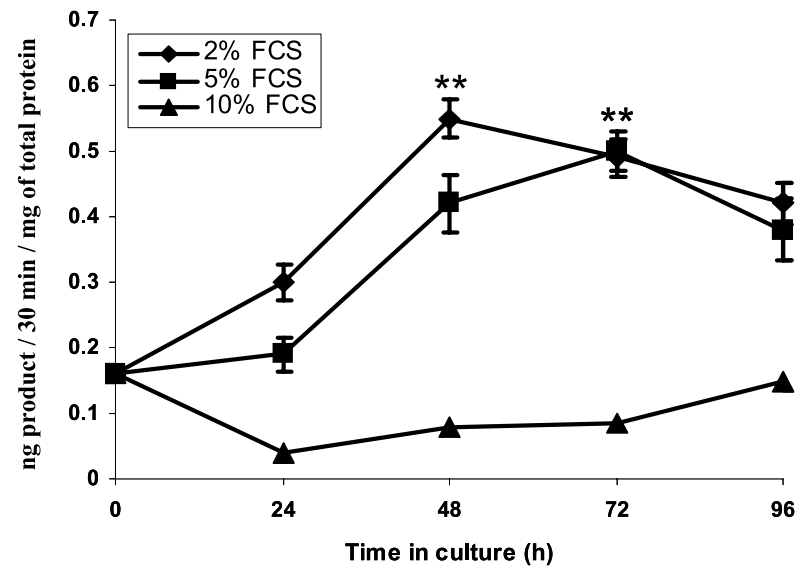

Figure 1 Decidualisation of murine endometrial stromal cells cultured in vitro. Stromal cells were isolated and cultured in the presence of $2 \%, 5 \%$ and $10 \%$ FCS. Quantitative measurement of ALP activity in cell lysates collected at daily intervals was used to assess decidualisation. ALP activity was significantly higher in stromal cell cultures supplemented with $2 \%$ FCS at $48 \mathrm{~h}(P<0.01)$ and $72 \mathrm{~h}(P<0.01)$ than with the $10 \%$ FCS treatment. ${ }^{* *} P<0.01$. The values represent average \pm S.E.M. of three separate replications.

increased with time in culture. The percentages of positive cells for ALP staining were at $24 \mathrm{~h}: 76 \%, 48 \mathrm{~h}: 82 \%$ and $72 \mathrm{~h}: 88 \%$ (over three culture experiments). Overall, desmin and ALP staining increased with time in culture, being maximal after 72-96 h. SSEA-3 was detected after $48 \mathrm{~h}$ in culture and then increased in intensity at later times. In contrast, SNA lectin binding decreased with time in culture. Cells stained with epithelium-specific antibody markers (H001 and H004) (Kimber et al. 1988) were less than $2 \%$ of cells by $48 \mathrm{~h}$ under these conditions (Fig. 1).

\section{Quantitation of stromal decidualisation response and the effect} of $\mathrm{PGE}_{2}$

To establish the responsiveness of the murine decidualisation model to PGs, the effect of $\mathrm{PGE}_{2}$ at 1,10 and $100 \mathrm{ng} / \mathrm{ml}$ on stromal cell decidualisation was assessed by measuring ALP activity in cell lysates. $\mathrm{PGE}_{2}$ had maximum effect at $10 \mathrm{ng} / \mathrm{ml}$, increasing ALP activity after $48 \mathrm{~h}$ relative to the control $(P<0 \cdot 01)$ and after 48 and $72 \mathrm{~h}$ relative to $1 \mathrm{ng} / \mathrm{ml}(P<0 \cdot 05)$ and $100 \mathrm{ng} / \mathrm{ml}$ $(P<0 \cdot 01)$ (Fig. 3). The lack of a dramatic effect of added $\mathrm{PGE}_{2}$ was predictable since it is produced by stromal cells. Therefore, the effect of IM, an inhibitor of PG synthesis, on decidualisation was examined. Stromal cells were treated without (control) or with three concentrations $\left(10^{-4}, 10^{-5}\right.$ and $\left.10^{-6} \mathrm{M}\right)$ of IM in the presence of $2 \%$ HIFCS, and the activity of ALP was measured (Fig. 4). There was a significant increase in the concentration of ALP in the control group compared with IM-treated cells at all concentrations. In $10^{-4} \mathrm{M}$ IM-treated cultures, a significant reduction in ALP activity was observed at 48 and $72 \mathrm{~h}(P<0.01$ and $P<0 \cdot 001$ respectively $)$ compared 


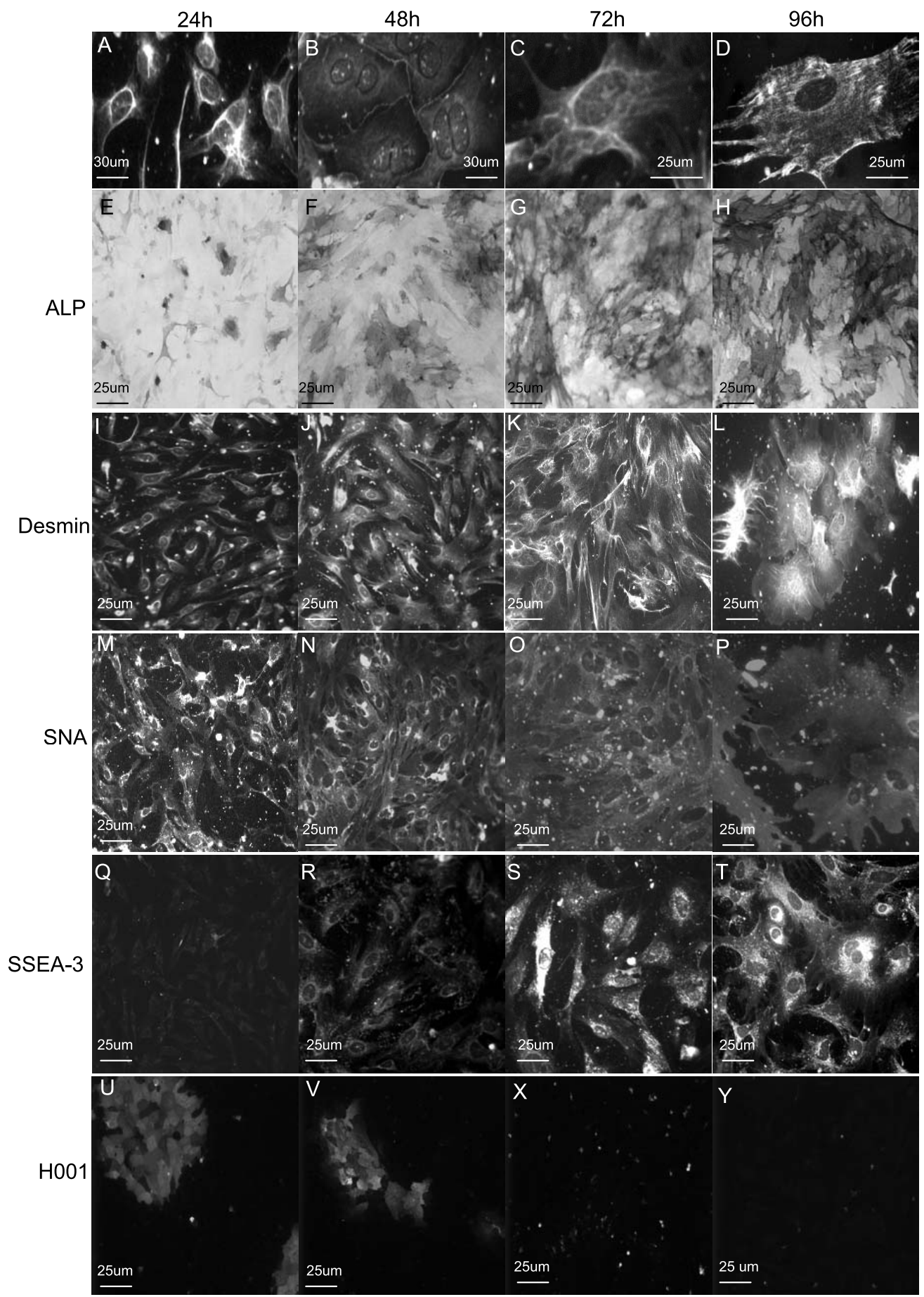

Figure 2 Decidualisation of murine stromal cells cultured in vitro. Stromal cells were cultured with 2\% FCS and assessed for decidualisation, using the increase in giant multinucleate cell (A-D) enzymatic reaction for ALP and immunofluorescence staining for decidual markers, desmin, and SSEA-3 and SNA binding. The intensity of staining and number of decidualised cells increased with time in culture for ALP (E-H), desmin $(\mathrm{I}-\mathrm{L})$ and SSEA-3 (Q-T). In contrast, SNA staining was reduced during culture (M-P). Staining for H001 was used to assess the level of contamination with luminal epithelium cells $(U-Y)$. 
Table 1 Summary of changes in the intensity of staining for decidual markers. The level of stanining was scored as --- for no staining and + (low), ++ (high), +++ (intense)

\begin{tabular}{|c|c|c|c|c|}
\hline & $24 \mathrm{~h}$ & $48 \mathrm{~h}$ & $72 \mathrm{~h}$ & $96 \mathrm{~h}$ \\
\hline \multicolumn{5}{|c|}{ Decidual marker } \\
\hline ALP & + & ++ & +++ & +++ \\
\hline Desmin & + & ++ & ++ & +++ \\
\hline SNA & +++ & ++ & ++ & + \\
\hline Desmin & --- & + & +++ & +++ \\
\hline
\end{tabular}

with the control group. In $10^{-6} \mathrm{M}$-treated cultures, a significant reduction in ALP activity was detected at $24 \mathrm{~h}$ $(P<0.05)$ and $72 \mathrm{~h}(P<0.001)$ in comparison to the control group. Maximum decrease in ALP activity was observed for $10^{-5} \mathrm{M}$ IM-treated cultures at $48 \mathrm{~h}$ compared with the control $(P<0 \cdot 001)$ and other concentrations of IM used $\left(10^{-4} \mathrm{M}, P<0 \cdot 05 ; 10^{-6} \mathrm{M}\right.$, $P<0 \cdot 01)$. At $72 \mathrm{~h}$, there was a significant decrease in the activity of ALP in all IM-treated cultures compared with the controls $(P<0 \cdot 001)$.

\section{Effects of LIF on proliferation and decidualisation of murine stromal cells}

To determine the effect of LIF on stromal cells, we cultured them in the absence (control) or presence of three concentrations of $\operatorname{LIF}(0 \cdot 5,5$ and $50 \mathrm{ng} / \mathrm{ml})$ for up to $72 \mathrm{~h}$. Proliferation of stromal cells was measured by counting the number of live cells which excluded trypan blue. Overall, cell numbers increased up to $48 \mathrm{~h}$ and decreased thereafter. The number of cells in LIF-containing medium was significantly increased in $5 \mathrm{ng} / \mathrm{ml}$ LIF-treated $(P<0 \cdot 01)$ and decreased in $0.5 \mathrm{ng} / \mathrm{ml}$ LIF-treated cultures $(P<0.01)$

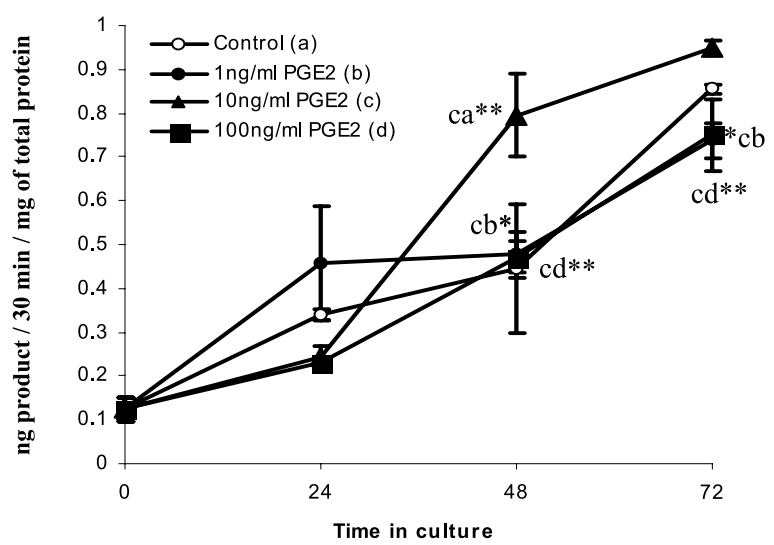

Figure 3 Effect of $\mathrm{PGE}_{2}$ on decidualisation of murine stromal cells cultured in vitro. $\mathrm{PGE}_{2}$ was added at 1,10 and $100 \mathrm{ng} / \mathrm{ml}$ during culture, and ALP activity was measured in cell lysates. $\mathrm{PGE}_{2}$ had maximum effect at $10 \mathrm{ng} / \mathrm{ml} \mathrm{PGE}$, increasing ALP activity after $48 \mathrm{~h}(P<0.01)$ relative to control, and after 48 and $72 \mathrm{~h}$ relative to $1 \mathrm{ng} / \mathrm{ml}(P<0 \cdot 05)$ and $100 \mathrm{ng} / \mathrm{ml}(P<0 \cdot 01)$. ${ }^{*} P<0 \cdot 05,{ }^{*} * P<0 \cdot 01$. The values represent average \pm S.E.M. of three separate replications.

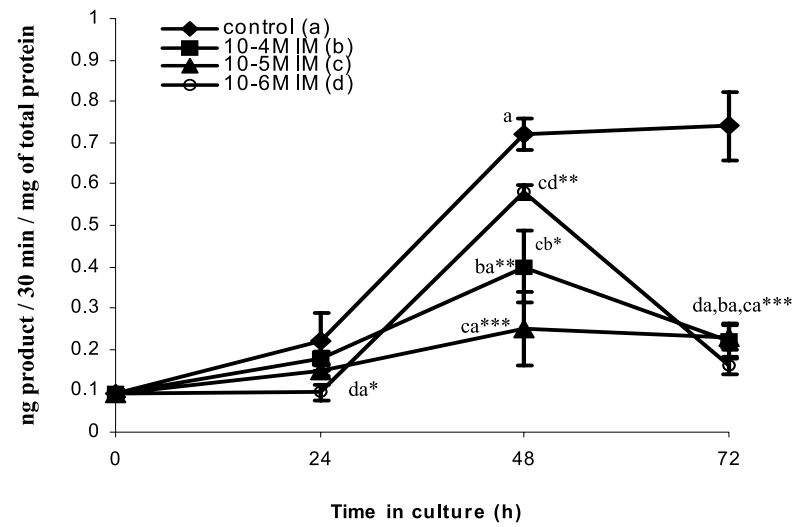

Figure 4 Effect of indomethacin (IM) on decidualisation of murine stromal cells cultured in vitro. Stromal cells were cultured in the presence of three concentrations of $10^{-4}, 10^{-5}$ and $10^{-6} \mathrm{M} \mathrm{IM}$ in the presence of $2 \%$ HIFCS, and the activity of ALP was measured. IM at all concentrations significantly decreased ALP activity. Maximum decrease in ALP activity was observed for $10^{-5} \mathrm{M}$ IM-treated cultures at 48 and $72 \mathrm{~h}$ compared with the control $(P<0.001)$ and at $48 \mathrm{~h}$ compared with other concentrations of IM used $\left(10^{-4} \mathrm{M}, P<0.05 ; 10^{-6} \mathrm{M}, P<0 \cdot 01\right)$. Significant decreases were also observed in $10^{-4} \mathrm{M}(48 \mathrm{~h}$ $(P<0.01), 72 \mathrm{~h}(P<0 \cdot 001))$, and $10^{-6} \mathrm{M}(24 \mathrm{~h}(P<0 \cdot 05), 72 \mathrm{~h}$ $(P<0.001))$-treated cultures relative to control. ${ }^{*} P<0.05$,

${ }^{*} * P<0 \cdot 01,{ }^{* * *} P<0 \cdot 001$. The values represent average \pm S.E.M. of three separate replications.

compared with the control at $24 \mathrm{~h}$ (Fig. 5). At $48 \mathrm{~h}$, cell numbers were greater in the $0.5 \mathrm{ng} / \mathrm{ml}$ group than the control $(P<0 \cdot 01)$. At $72 \mathrm{~h}$, no differences were observed between control and LIF-treated cells.

We also examined the effect of LIF on ALP activity and $\mathrm{PGE}_{2}$ production in cultured stromal cells (Figs 6 and 7). LIF at all concentrations and time points decreased ALP activity compared with the control, and this inhibition was dose-dependent, with the greatest effect at 5 and $50 \mathrm{ng} / \mathrm{ml}$ LIF (Fig. 6). At $72 \mathrm{~h}$, there were no significant differences between 5 and $50 \mathrm{ng} / \mathrm{ml}$ LIF or between $0.5 \mathrm{ng} / \mathrm{ml}$ and the control. Based on these results, the concentration of $5 \mathrm{ng} / \mathrm{ml}$ LIF was used for the later experiments. When $\mathrm{PGE}_{2}$ was assessed, a significant increase in $\mathrm{PGE}_{2}$ levels was found with time in culture in all LIF-treated cultures and controls (Fig. 7). However, $\mathrm{PGE}_{2}$ production was not significantly different between LIF-treated groups and control or between different LIF concentrations. Thus, LIF did not stimulate or decrease $\mathrm{PGE}_{2}$ production in these cells in vitro. The effect of LIF and LIF inhibitor (LIF05) on ALP levels was assessed in stromal cells cultured in the absence (control) or presence of $5 \mathrm{ng} / \mathrm{ml}$ LIF, $50 \mathrm{ng} / \mathrm{ml}$ inhibitor and $5 \mathrm{ng} / \mathrm{ml}$ LIF plus $50 \mathrm{ng} / \mathrm{ml}$ inhibitor (Fig. 8). LIF inhibitor significantly increased ALP concentration at both time points compared with LIFtreated cells $(P<0 \cdot 05)$. In addition, there were significant differences between cultures in LIF alone and LIF plus LIF05 $(P<0 \cdot 05)$. Again, LIF significantly reduced ALP 


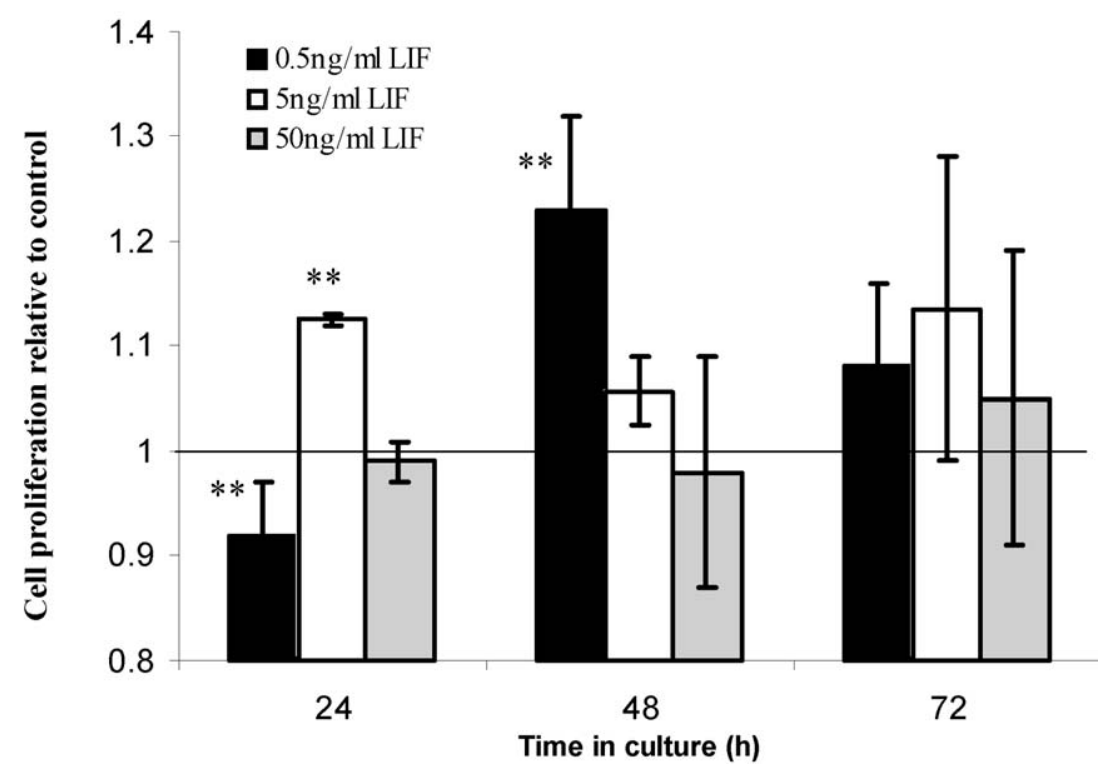

Figure 5 Effects of LIF on the cell numbers for murine stromal cells cultured in vitro. At $24 \mathrm{~h}$, cell numbers were significantly lower in $0.5 \mathrm{ng} / \mathrm{ml}$ LIF-treated cultures and significantly higher in $5 \mathrm{ng} / \mathrm{ml}$ LIF-treated cultures relative to the control $\left({ }^{* * P}<0 \cdot 01\right)$. No difference was observed between $50 \mathrm{ng} / \mathrm{ml}$ LIF-treated cultures and controls. At $48 \mathrm{~h}$, cell numbers were significantly higher only in $0.5 \mathrm{ng} / \mathrm{ml}$-treated cultures $(* * P<0 \cdot 01)$. No significant differences were observed between the other LIF-treated groups and controls. At 72 h, no differences were observed in any group compared with controls. Cell number is recorded relative to control indicated by the line at 1 on bar graph.

activity at $48 \mathrm{~h}(P<0.01)$ and $72 \mathrm{~h}(P<0.05)$ compared with the control. There were no significant differences between control and LIF05 or between control and LIF plus LIF05 at either time point. These observations suggested that LIF inhibited ALP activity in 2\% serumcontaining medium. Therefore, because of the possible compounding effect of serum in the medium, stromal cells were cultured for $24 \mathrm{~h}$ with $2 \%$ FCS, and then the serum-containing medium was removed. They were divided into four treatment groups, without FCS: no additive (control); $5 \mathrm{ng} / \mathrm{ml} \mathrm{LIF;} 50 \mathrm{ng} / \mathrm{ml}$ inhibitor and $5 \mathrm{ng} / \mathrm{ml} \mathrm{LIF} \mathrm{plus} 50 \mathrm{ng} / \mathrm{ml}$ inhibitor in serum-free conditions. The data were analysed for differences in activity of ALP at $48 \mathrm{~h}$ of culture (Fig. 9). There were no significant differences in ALP activity between any of the groups in the absence of serum.

Production of LIF by stromal cells and influence of LIF on its receptor

We asked whether stromal cells make LIF in vitro. Production of LIF by the cells cultured up to $96 \mathrm{~h}$ was measured by ELISA of culture medium (Fig. 10). The value for cell-free culture medium subtracted to exclude any LIF in the added medium $((\mathrm{LIF})=0.005 \mathrm{ng} / \mathrm{ml}$ in culture medium plus $2 \%$ serum). LIF production increased between $0-24$ and $24-48 \mathrm{~h}$ of culture, and then produc- tion plateaued at $2.5 \mathrm{ng} / \mathrm{ml}$ at $24 \mathrm{~h} / \mathrm{mg}$ protein, or gradually decreased up to $96 \mathrm{~h}$ of culture. Thus, in a 24-h period, the cells were producing between 1.6 and $2.5 \mathrm{ng} / \mathrm{ml} \mathrm{LIF} / \mathrm{mg}$ protein. With an average cell protein of $0.15 \mathrm{mg} /$ well at $24 \mathrm{~h}$, this would give $0.24 \mathrm{ng}$ LIF/well per $24 \mathrm{~h}$ at $24 \mathrm{~h}$ and with an average cell protein of $0.35 \mathrm{mg} /$ well at $48 \mathrm{~h}, 0.88 \mathrm{ng} \mathrm{LIF} /$ well per $24 \mathrm{~h}$ at $48 \mathrm{~h}$, accounting for the difference between the control and the inhibitor alone in the experiments above.

To assess the effect of culture per se or the addition of LIF on expression of LIF receptor, the transcript for LIF receptor was examined by a semi-quantitative method. cDNA was normalised, using $\beta$-actin. In cDNA isolated from freshly collected day 4 stromal cells, a band was first detected after 20 cycles, while in freshly isolated day 2 cells it appeared after 26 cycles (Fig. 11A). When LIF-R $\beta$ was assessed in cDNA from cultured cells, it was found that the band was first detected at 20 cycles irrespective of the number of days in culture. In addition, no differences in the cycle number at which a band could first be detected were found between day 2 and day 4 stromal cells after $24 \mathrm{~h}$ or more in culture (Fig. 11B and C). Thus, while in vivo there are differences in transcript abundance between day 2 and day 4 of pregnancy, these differences disappear after culture. For cultured cells, there was no difference between control and any dose of LIF on the cycle number at which LIF-R $\beta$ was detected (Fig. 11B and C). 


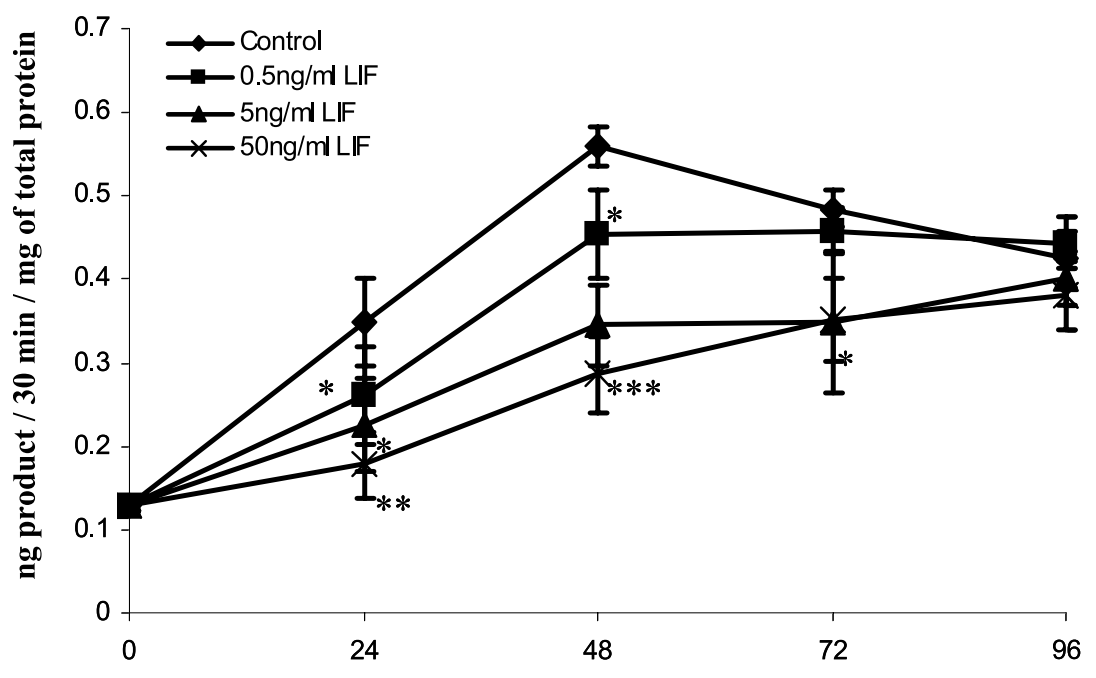

Time in culture (h)

Figure 6 Effects of LIF on ALP activity in murine stromal cells cultured in vitro. Stromal cells were cultured in the absence (control) or presence of $0 \cdot 5,5$ and $50 \mathrm{ng} / \mathrm{ml}$ LIF. The activity of ALP measured in cell lysates was significantly reduced in all LIF-treated groups in comparison with the control in each time point. ${ }^{*} P<0 \cdot 05,{ }^{* *} P<0 \cdot 01,{ }^{* *} P<0 \cdot 001$. The values represent average \pm S.E.M. of six separate experiments.

\section{Discussion}

We employed an in vitro culture system for murine uterine stromal cells based on that employed for the rat (Inaba et al.
1988). In these cultures, mouse stromal cells spontaneously decidualise by a number of criteria, including increased activity of ALP, which was used as a quantitative measure of decidualisation. In establishing the system, the effects of

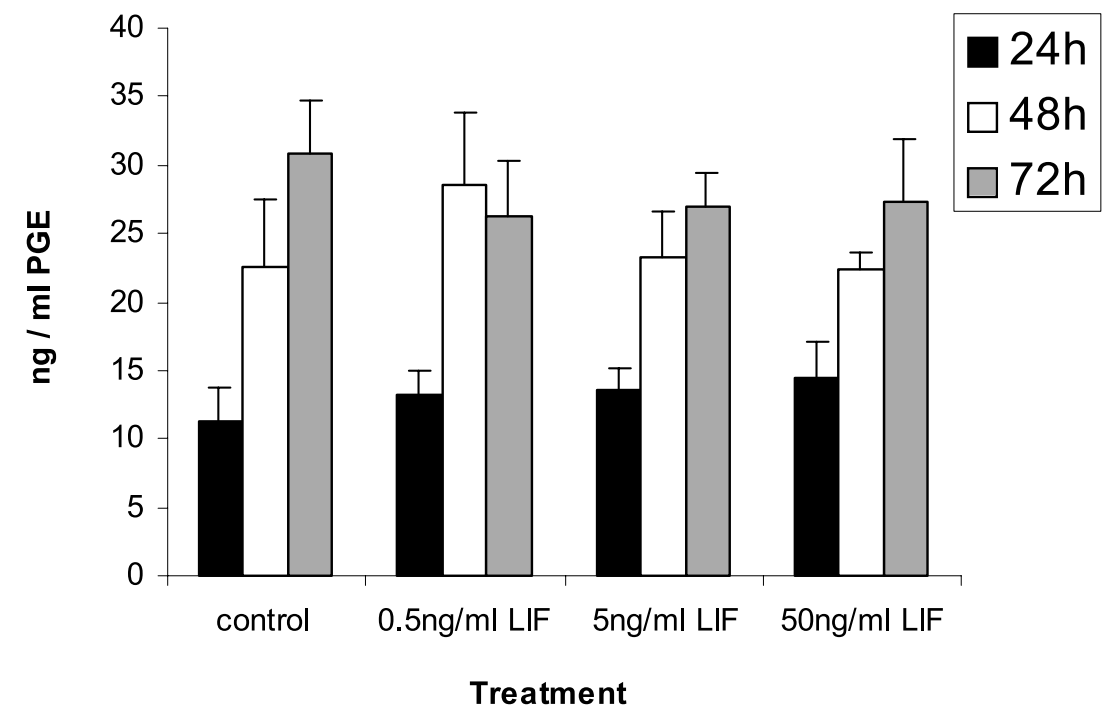

Figure 7 Effects of LIF on production of $\mathrm{PGE}_{2}$ by cultured endometrial murine stromal cells over 24-h periods up to $72 \mathrm{~h}$ in culture, expressed as $\mathrm{ng} \mathrm{PGE}_{2} / \mathrm{ml}$ per $\mu \mathrm{g}$ protein. Stromal cells were cultured in the absence (control) or presence of $0.5,5$ and $50 \mathrm{ng} / \mathrm{ml}$ LIF. Concentration of $\mathrm{PGE}_{2}$ in culture media as measured by RIA increased significantly with time in culture. However, there were no significant differences in $\mathrm{PGE}_{2}$ levels at different LIF concentrations or between LIF and control groups. The data represent average \pm S.E.M. in three separate experiments. 


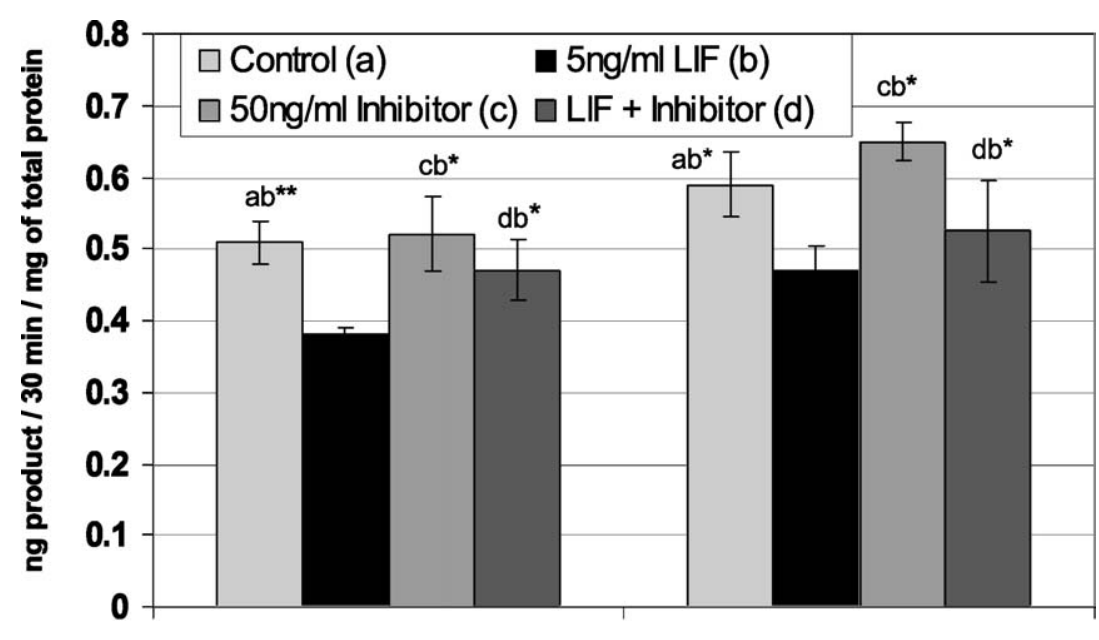

48

72

Time in culture (h)

Figure 8 Effects of LIF inhibitor on ALP activity in cultured murine endometrial stromal cells. LIF inhibitor significantly increased ALP concentration at all time points compared with LIF-treated cells $\left({ }^{*} P<0 \cdot 05\right)$. There was also a significant difference between LIF alone and in the presence of inhibitor, which had a slight stimulatory effect at $48 \mathrm{~h}\left({ }^{*} P<0 \cdot 05\right)$. There were no significant differences between control and LIF inhibitor or between control and LIF plus inhibitor at either time point.

three levels of FCS were tested. In 2\% FCS, ALP activity in cell lysates showed a rapid increase up to $48 \mathrm{~h}$ and then declined. The increase in ALP was slower in cultures containing 5\% serum, and ALP activity was suppressed in cultures with $10 \%$ serum. ALP is a glycosylated, membrane-bound metalloenzyme, and its activity has

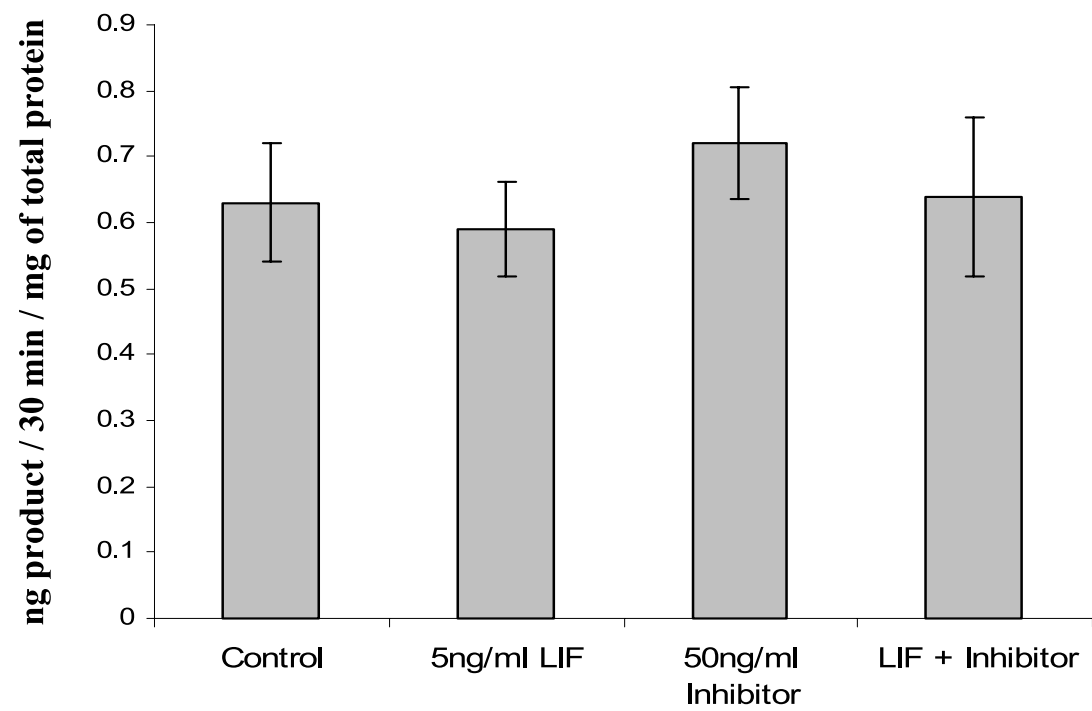

\section{Treatment}

Figure 9 Effects of LIF and its inhibitor on ALP activity in serum-free cultures. Murine endometrial stromal cells were cultured for an initial period of $24 \mathrm{~h}$ with $2 \%$ FCS and then divided into four treatment groups: no additive, $5 \mathrm{ng} / \mathrm{ml} \mathrm{LIF}, 50 \mathrm{ng} / \mathrm{ml}$ inhibitor and $5 \mathrm{ng} / \mathrm{ml}$ LIF plus $50 \mathrm{ng} / \mathrm{ml}$ inhibitor in serum-free conditions. The histogram compares mean \pm S.E.M. of ALP activity at the 48-h time point in cell lysates from three different experiments. 


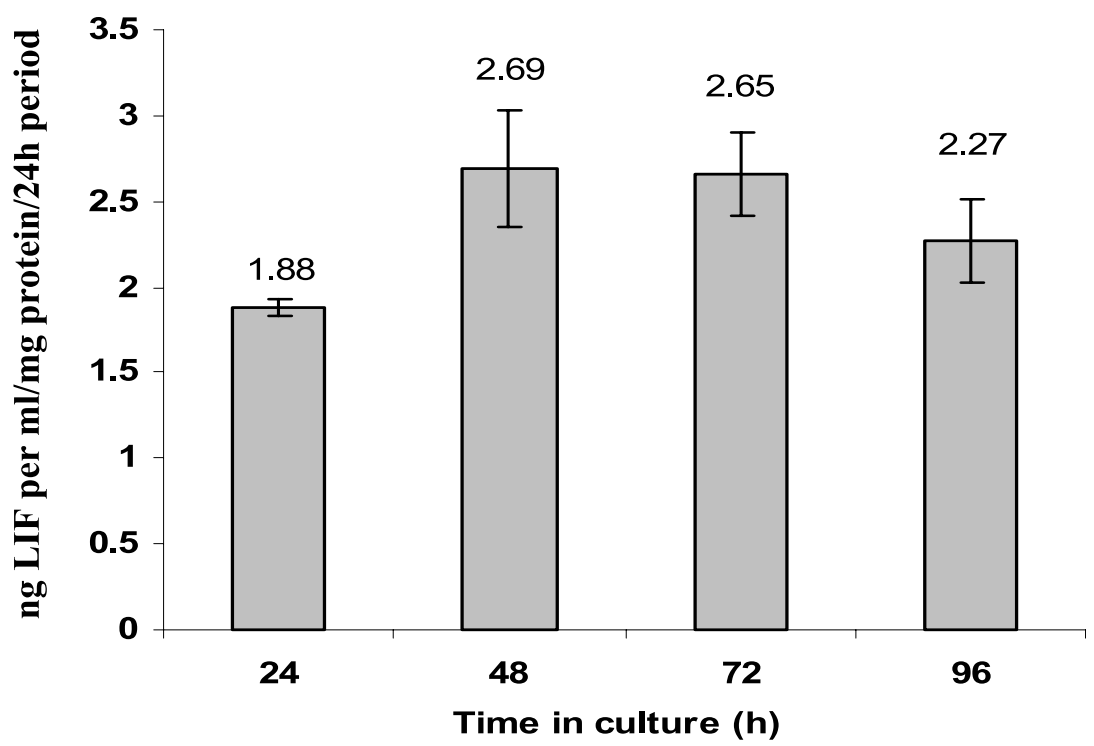

Figure 10 Production of LIF by cultured murine endometrial stromal cells. Uterine stromal cells were isolated and cultured for up to $96 \mathrm{~h}$ with $2 \%$ FCS. The concentration of LIF in culture media was measured by ELISA and subtracted from the concentration of LIF in FCS. The values represent mean \pm S.E.M. from three separate experiments.

been used extensively as a decidual marker for in vivo studies on rat and mouse uteri (Buxton \& Murdoch 1980, Kennedy \& Ross 1993, Milligan et al. 1995) and in vitro culture of rat uterine stromal cells (Yee \& Kennedy 1991, Kennedy \& Ross 1997). Johanson and Wide (1994) found an increase in ALP mRNA during pregnancy that correlated with the increase in ALP activity. The results of the present study confirm that the degree of cellular differentiation is dependent on the concentration of serum in culture. At higher levels of FCS, stromal cells had higher proliferation rates, but the percentage of ALP-positive cells was $3-10 \%$ higher for $2 \%$ serum than $10 \%$ serum supplemented cultures (data not shown), and the ALP activity was up to seven times greater. Attempts to grow cells in less than $2 \%$ serum gave inconsistent results and, in our hands, generally did not lead to established primary cultures. This was not due to differences in the serum batch, since we used the same batch throughout this study. Serum contains growth factors, hormones, macromolecules and other components and is added to cell cultures as a survival agent or stimulator of proliferation. It has been reported that FCS contains serum antiapoptotic factor (SAF), which regulates Fas-mediated apoptosis (Kikuchi et al. 1995). We found that $2 \%$ serum stimulated adequate cell proliferation while still allowing good differentiation of decidualised cells.

Decidualisation of cultured stromal cells was confirmed by their expression of ALP, desmin, SNA-ligand and SSEA-3. By histochemical staining, ALP has been shown in luminal epithelium from day 2 of pregnancy and decidualising stromal cells have been shown from day 6 in mouse uterus (Bucci \& Murphy 1995). In the present study, the number of ALP-positive cells increased with time in culture. The intermediate filament protein desmin has also been used as a marker of decidualisation (Glasser \& Julian 1986), and this molecule also showed increased expression as culture progressed. There are also modifications in the surface glycans of rat and mouse uterine stromal cells during the decidual remodelling of extracellular matrix (Jones et al. 1993). For instance, a reduction in SNA binding in the murine primary decidual zone was reported on day 6 of pregnancy (Jones et al. 1996). We observed intense staining for SNA lectin in the stroma on day 2 of pregnancy, but after implantation on day 5 the staining was reduced in the subepithelial stroma adjacent to the embryo (data not shown). In the present study, SNA lectin binding was high at $24 \mathrm{~h}$ and decreased thereafter, an obervation which is in keeping with the previous observations. SSEA-3 is a carbohydrate-antigen present on the zygote, in early cleavage stages and in post-implantation embryos (Shevinsky et al. 1982). It is expressed in mouse uterine decidual cells after day 6 of pregnancy (Fox et al. 1984). For this epitope, the intensity of staining was found to increase with time of culture. Thus, expression of several decidual markers is similar in vitro to that observed in vivo, confirming the utility of the culture system.

PGs are known to contribute to various cellular functions, including proliferation and decidualisation (Rankin et al. 1979). Indeed, rodent stromal cells produce endogenous PGs that stimulate ALP activity during culture (Yee \& Kennedy 1991). After endogenous PG synthesis was 
(A)

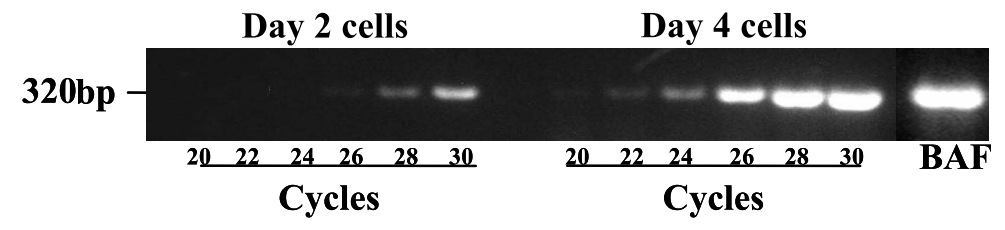

(B)

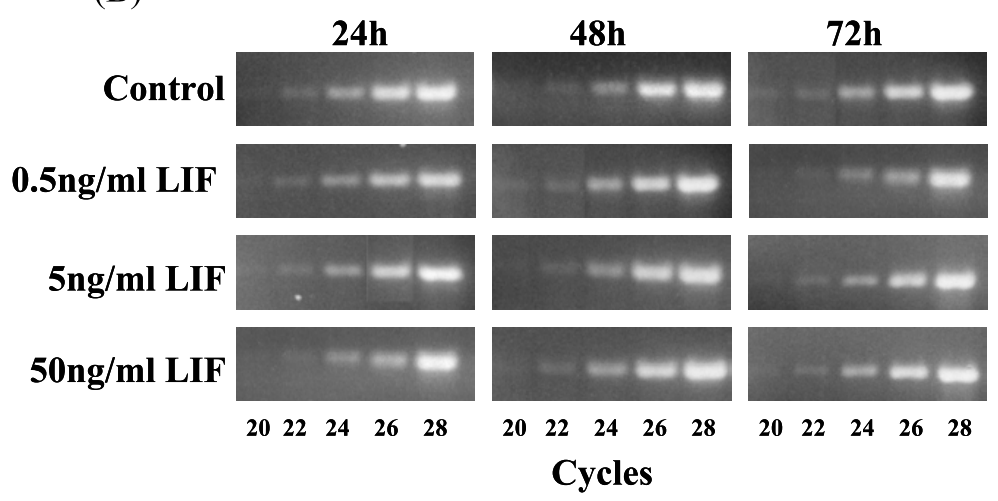

(C)

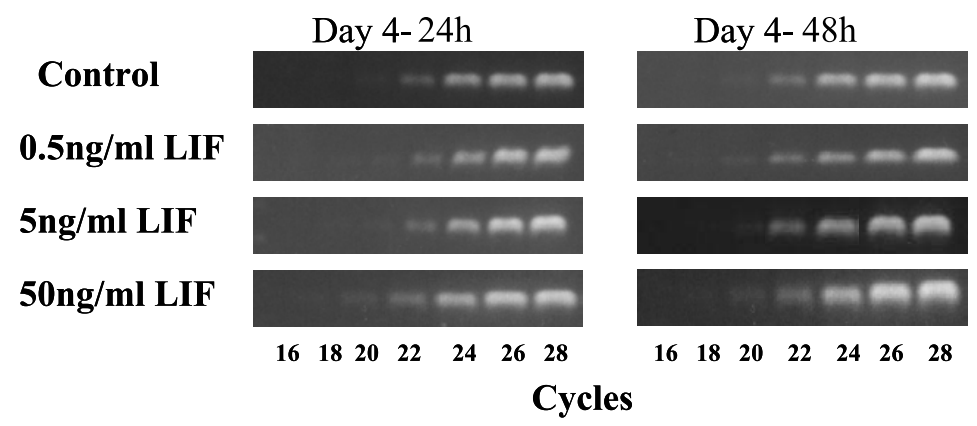

Figure 11 Expression of mRNA for LIF receptor in murine endometrial stromal cells. Total RNA was extracted from either of freshly collected stromal cells (A) or cells cultured from day-2 (B) and day-4 (C) pregnant mice for 24-72 h. Expression of mRNA for LIF receptor was assessed by semi-quantitative RT-PCR on $1 \mu \mathrm{g}$ of RNA in each lane at different cycles. In freshly collected day-4 stromal cells, the first band was detected after 20 cycles while in day-2 cells it appeared after 26 cycles (A), but there were no differences between cultured stromal cells in the control groups and LIF-treated cells from either day (B and C).

inhibited by IM, PG infused into the lumen of sensitised rat uteri restored the endometrial vascular permeability response and decidualisation (Kennedy \& Lukash 1982, Hamilton \& Kennedy 1994). Among various PGs, PGE 2 and prostacyclin have been considered as primary candidates involved in implantation and decidualisation (Kennedy 1985, Daniel \& Kennedy 1987, Kennedy \& Ross 1993, Pakrasi 1997, Lim et al. 1999, Papay \& Kennedy 2000). $\mathrm{PGE}_{2}$ receptor subtypes show tissue specific expression in the peri-implantation mouse uterus (Lim \& Dey 1997, Yang et al. 1997), and PGs and mRNAs and proteins for receptors and enzymes involved in PG synthesis are highly expressed in the implantation site and decidual cells in mouse (Chakraborty et al. 1996,
Pakrasi 1997, Yang et al. 1997, Ni et al. 2002b). $\mathrm{PGE}_{2}$ may exert its effect through upregulation of cAMP activity (Yee \& Kennedy 1991). Alternatively, it has been suggested that the major mediator of decidualisation in mice is prostacyclin $\left(\mathrm{PGI}_{2}\right)$, acting via the nuclear hormone receptor PPAR $\delta$ (Lim et al. 1999). $\mathrm{PGE}_{2}$ also enhances decidualisation of human endometrial cells cultured in the presence of progesterone (Frank et al. 1994). In the present study, ALP activity increased in cultures supplemented with $\mathrm{PGE}_{2}$ compared with the control and with time in culture. An amount of $10 \mathrm{ng} / \mathrm{ml} \mathrm{PGE}_{2}$ significantly stimulated ALP activity compared with 1 and $100 \mathrm{ng} / \mathrm{ml} \mathrm{PGE}_{2}$, suggesting that superphysiological amounts of $\mathrm{PGE}_{2}$ may lead to receptor downregulation. Inclusion of IM, an 
inhibitor of PG synthesis, reduced ALP activity at all concentration used, and addition of $\mathrm{PGE}_{2}$ reversed this effect in a dose-dependent manner. Similar results have been reported in rat stromal cells (Kennedy \& Ross 1993, 1997), and such PG-mediated stimulation of ALP has been reported in osteoblasts (Sisk et al. 2001).

Evidence for the essential role of LIF in implantation of the mouse embryo comes from the infertility of LIF-null female mice together with the tightly regulated transient expression just before implantation (Bhatt et al. 1991, Stewart et al. 1992, Stewart \& Cullinan 1997). Furthermore, decidualisation has been shown to be severely defective in LIF-null females (Chen et al. 2000). Since LIF-R $\beta$ is expressed at the highest levels by the luminal epithelium, it is inferred that LIF exerts its major effect on decidualisation via signals transduced by that tissue (Cheng et al. 2002). In the present study, we examined the direct effect of LIF on stromal cells in vitro. Although these cells did not comprise a pure population, our own observations and those of others (Jacobs \& Carson 1993) indicate that in this type of culture less than $2 \%$ cells are epithelial and less than $1 \%$ consist of leukocytes by $48 \mathrm{~h}$ of culture. Addition of LIF to murine stromal cells in culture caused a concentration-dependent inhibition of ALP activity compared with the control. The percentage of ALP-positive cells was also lower for LIF-treated cultures (data not shown). In vitro, LIF similarly suppresses ALP activity in osteoblast-like cells (Thiede et al. 1988) and rat calvaria cell cultures (Malaval et al. 1995). The suppressing effect of LIF on ALP activity is paralleled by a slight stimulatory effect on cell numbers, observed at $24 \mathrm{~h}$ in cultures with $5 \mathrm{ng} / \mathrm{ml} \mathrm{LIF}$, but only later, at $48 \mathrm{~h}$, in medium with only $0.5 \mathrm{ng} / \mathrm{ml}$ added LIF. At $50 \mathrm{ng} / \mathrm{ml}$, it had no influence on cell numbers, due to a threshold effect or possibly because of downregulation of its receptor. However, at $50 \mathrm{ng} / \mathrm{ml}$, LIF is still effective at blocking ALP activity to a level at least equivalent to $5 \mathrm{ng} / \mathrm{ml}$ added LIF.

Mouse uterine stromal cells produce LIF during culture, and the amount of LIF produced/24-h period is highest at 24-48 $\mathrm{h}$ and then decreases. So we must consider the effects this endogenously produced LIF has on both proliferation and differentiation of stromal cells. At $48 \mathrm{~h}$ in $0.5 \mathrm{ng} / \mathrm{ml}$-treated cultures, there is, on average, an extra $0.88 \mathrm{ng} /$ well of endogenously produced LIF present that can stimulate proliferation. The actual concentration is therefore approximately $1.3 \mathrm{ng} / \mathrm{ml}$. This is apparently sufficient to induce equivalent increase in cell numbers by $48 \mathrm{~h}$ to that triggered by $5 \mathrm{ng} / \mathrm{ml}(+0.88 \mathrm{ng} / \mathrm{ml}$ produced by the cells) after $24 \mathrm{~h}$ of culture. Inhibition of stromal apoptosis by LIF cannot be ruled out.

To further investigate the role of LIF in decidualisation, we used hLIF 05, a mutant form of LIF that competes with LIF for binding to its receptor, which has already been demonstrated to be a powerful antagonist of LIF (Hudson et al. 1996). We observed that LIF 05 slightly enhanced
ALP activity compared with control cultures, presumably due to the antagonism of LIF produced by the cells. We also observed that, in serum-free cultures, we could detect no significant difference in ALP activity between LIFtreated and untreated groups or in the presence of the inhibitor. This suggests that LIF may act with serum factors to inhibit ALP. It is notable that the cells cease proliferation and either differentiate or die very quickly in the absence of serum, suggesting very rapid commitment to one or other of these pathways and lack of maintenance of a plastic proliferating population. It is probable that the lack of other factors precludes us from observing an effect of LIF.

LIF acts on cells by binding to its heterodimeric receptor, comprising gp130 and LIF-R $\beta$ (Gearing et al. 1991). By in situ hybridisation, LIF-R $\beta$ mRNA appears to be mainly localised to the luminal epithelium and gp130 mainly to the glandular epithelium on days $3-5$ of pregnancy (Cheng et al. 2001). However, LIF-R $\beta$ mRNA is detected strongly in decidua from day 6 of pregnancy, and LIF-R $\beta$ and gp130 protein have been detected in the stroma on day 5 (Yang et al. 1995, Ni et al. 2002). Thus, although the initial site of action for LIF on day 4 may be the luminal epithelium (LE), it is clear that LIF can interact with the decidualising stroma, particularly later during the implantation process, and our data indicate that this interaction may be a repressive one.

Relative measurements of transcript level for LIF-R $\beta$ suggested the presence of greater numbers of transcripts in freshly isolated stromal cells on day 4 than day 2 of pregnancy. However, it is important to remember that freshly isolated cells are a mixed population containing glandular epithelial cells, leukocytes and endothelial cells as well as fibroblastic cells. By 24 and $48 \mathrm{~h}$ of culture, stromal cells from days 2 and 4 of pregnancy appeared to have similar levels of transcripts for LIF-R $\beta$. This was not influenced by the addition of LIF to the culture medium. It seems that cultured stromal cells retain expression of LIF-R $\beta$, and some upregulation may be apparent for stromal cells from day 2 of pregnancy, which are capable of spontaneous decidualisation in vitro in the absence of stimulation in vivo by nidatory oestrogen. Our results tentatively suggest that the effect of LIF in suppressing decidualisation of stromal cells may be independent of any negative (or positive) feedback regulation on its own receptor mRNA. However, modulation of gp130 mRNA levels or feedback on post-transcriptional events cannot be ruled out.

Overall, we have shown that uterine stromal cells decidualise in vitro with a time course dependent on the concentration of serum in culture. LIF reduces decidualisation of mouse uterine stromal cells during culture, and this effect was suppressed by a competitive inhibitor of LIF. In vitro, decidualising stromal cells produce LIF, and this reflects the known expression of LIF transcripts by decidual cells in vivo. Although it appears that LIF has a 
major critical target in the LE which is essential for implantation, we suggest that LIF may also have an important role in spatially restricting the decidual response to the implantation site at days 4-5 of pregnancy, when additional localised embryonic signals, transduced through a LIF-stimulated luminal epithelium, promote decidualisation. Its transient expression and source in uterine glands (Bhatt et al. 1991), together with receptor expression by decidua ( $\mathrm{Ni}$ et al. 2002a), is in keeping with such a role. Thus, at the implantation site, as the area of initial decidualisation spreads through the stroma towards the myometrium, from the region adjacent to the implanting embryo, the uterine glands become restricted to the region directly subjacent to the muscle layers. However, in the inter-implantation site (where decidualisation does not occur), they remain dispersed through the stroma. LIF protein may still be present to enact this inhibition after day 4 of pregnancy, since, although LIF mRNA decreases, it is still detectable on day 5 by Northern blotting (Bhatt et al. 1991), and LIF protein is reported to be expressed stably through the first 5 days of pregnancy in myometrium (Yang et al. 1995), which would also be suitably placed as a source of a decidual restraining factor. Finally, expression of LIF by decidualising stroma itself may act to limit decidualisation by autocrine feedback mechanisms, since we have shown that both the receptor mRNA and LIF protein are produced by decidualised stromal cells in vitro and LIF-R $\beta$ and gp130 are co-expressed in decidua in vivo (Ni et al. 2002a).

\section{Acknowledgement}

We are most grateful to the Biotechnology and Biological Sciences Research Council UK (grant code: S11534) for funding this project.

\section{References}

Abrahamsohn PA \& Zorn TM 1993 Implantation and decidualization in rodents. Journal of Experimental Zoology 266 603-628.

Ansell JD, Barlow PW \& McLaren A 1974 Binucleate and polyploid cells in the decidua of the mouse. Journal of Embryology and Experimental Morphology 31 223-227.

Arnold JT, Kaufman DG, Seppala M \& Lessey BA 2001 Endometrial stromal cells regulate epithelial cell growth in vitro: a new co-culture model. Human Reproduction 16 836-845.

Aubert J, Dessolin S, Belmonte N, Li M, McKenzie FR, Staccini L, Villageois P, Barhanin B, Vernallis A, Smith AG et al. 1999 Leukemia inhibitory factor and its receptor promote adipocyte differentiation via the mitogen-activated protein kinase cascade. Journal of Biological Chemistry 274 24965-24972.

Bany BM \& Kennedy TG 1999 Role of interleukin 1 in the regulation of cyclooxygenase gene expression in rat endometrial stromal cells. Journal of Reproduction and Fertility 115 125-131.

Bany BM, Zhang X \& Kennedy TG 1998 Effects of epidermal growth factor and interleukin-1 alpha on plasminogen activator secretion and decidualization in rat endometrial stromal cells. Biology of Reproduction 59 131-135.
Benson GV, Lim H, Paria BC, Satokata I, Dey SK \& Maas RL 1996 Mechanisms of reduced fertility in Hoxa-10 mutant mice: uterine homeosis and loss of maternal Hoxa-10 expression. Development 122 2687-2696.

Bhatt H, Brunet LJ \& Stewart CL 1991 Uterine expression of leukemia inhibitory factor coincides with the onset of blastocyst implantation. PNAS 88 11408-11412.

Bucci M \& Murphy CR 1995 Alkaline phosphatase distribution in the plasma membrane of uterine epithelial cells is markedly altered during early pregnancy in the rat. Cell Biology International 19 921-928.

Buxton LE \& Murdoch RN 1980 Behaviour and properties of membrane-bound mouse uterine alkaline phosphatase during early pregnancy. Australian Journal of Biological Sciences 33 539-548.

Chakraborty I, Das SK, Wang J \& Dey SK 1996 Developmental expression of the cyclo-oxygenase- 1 and cyclo-oxygenase- 2 genes in the peri-implantation mouse uterus and their differential regulation by the blastocyst and ovarian steroids. Journal of Molecular Endocrinology 16 107-122.

Chen JR, Cheng JG, Shatzer T, Sewell L, Hernandez L \& Stewart CL 2000 Leukemia inhibitory factor can substitute for nidatory estrogen and is essential to inducing a receptive uterus for implantation but is not essential for subsequent embryogenesis. Endocrinology 141 4365-4372.

Cheng JG, Chen JR, Hernandez L, Alvord WG \& Stewart CL 2001 Dual control of LIF expression and LIF receptor function regulate Stat 3 activation at the onset of uterine receptivity and embryo implantation. PNAS 98 8680-8685.

Cheng JG, Rodriguez CI \& Stewart CL 2002 Control of uterine receptivity and embryo implantation by steroid hormone regulation of LIF production and LIF receptor activity: towards a molecular understanding of 'the window of implantation'. Reviews in Endocrine and Metabolic Disorders 3 119-126.

Daniel SA \& Kennedy TG 1987 Prostaglandin $E_{2}$ enhances uterine stromal cell alkaline phosphatase activity in vitro. Prostaglandins 33 241-252.

Evans CA, Kennedy TG, Patrick JE \& Challis JR 1982 The effects of indomethacin on uterine activity and prostaglandin (PG) concentrations during labor induced by administering ACTH to fetal sheep. Canadian Journal of Physiology and Pharmacology 60 1200-1209.

Finn CA 1966 Endocrine control of endometrial sensitivity during the induction of the decidual cell reaction in the mouse. Journal of Endocrinology 36 239-248.

Finn CA \& McLaren A 1967 A study of the early stages of implantation in mice. Journal of Reproduction and Fertility 13 259-267.

Fox NW, Damjanov I, Knowles BB \& Solter D 1984 Stage-specific embryonic antigen 3 as a marker of visceral extraembryonic endoderm. Developmental Biology 103 263-266.

Frank GR, Brar AK, Cedars MI \& Handwerger S 1994 Prostaglandin $\mathrm{E}_{2}$ enhances human endometrial stromal cell differentiation. Endocrinology $134258-263$.

Gambel P, Rossant J, Hunziker RD \& Wegmann TG 1985 Origin of decidual cells in murine pregnancy and pseudopregnancy. Transplantation 39 443-445.

Gearing DP, Thut CJ, VandeBos T, Gimpel SD, Delaney PB, King J, Price V, Cosman D \& Beckmann MP 1991 Leukemia inhibitory factor receptor is structurally related to the IL-6 signal transducer, gp130. EMBO Journal 10 2839-2848.

Gearing DP, VandenBos T, Beckmann MP, Thut CJ, Comeau MR, Mosley B \& Ziegler SF 1992 Reconstitution of high affinity leukaemia inhibitory factor (LIF) receptors in haemopoietic cells transfected with the cloned human LIF receptor. Ciba Foundation Symposium 167 245-255.

Gendron RL, Paradis H, Hsieh-Li HM, Lee DW, Potter SS \& Markoff E 1997 Abnormal uterine stromal and glandular function associated with maternal reproductive defects in Hoxa-11 null mice. Biology of Reproduction 56 1097-1105. 
Glasser SR \& McCormack SA 1979 Estrogen-modulated uterine gene transcription in relation to decidualization. Endocrinology 104 1112-1118.

Glasser SR \& Julian J 1986 Intermediate filament protein as a marker of uterine stromal cell decidualization. Biology of Reproduction $\mathbf{3 5}$ 463-474.

Glasser SR, Lampelo S, Munir MI \& Julian J 1987 Expression of desmin, laminin and fibronectin during in situ differentiation (decidualization) of rat uterine stromal cells. Differentiation $\mathbf{3 5}$ 132-142.

Granstrom E \& Kindahl H 1983 Assay methods for prostaglandins and related compounds. Advances in Prostaglandin, Thromboxane, and Leukotriene Research 11 173-179.

Haines BP, Voyle RB \& Rathjen PD 2000 Intracellular and extracellular leukemia inhibitory factor proteins have different cellular activities that are mediated by distinct protein motifs. Molecular Biology of the Cell 11 1369-1383.

Hamilton GS \& Kennedy TG 1994 Uterine vascular changes after unilateral intrauterine infusion of indomethacin and prostaglandin $\mathrm{E}_{2}$ to rats sensitized for the decidual cell reaction. Biology of Reproduction $\mathbf{5 0}$ 757-764.

Hudson KR, Vernallis AB \& Heath JK 1996 Characterization of the receptor binding sites of human leukemia inhibitory factor and creation of antagonists. Journal of Biological Chemistry 271 11971-11978.

Inaba T, Wiest WG, Strickler RC \& Mori J 1988 Augmentation of the response of mouse uterine epithelial cells to estradiol by uterine stroma. Endocrinology 123 1253-1258.

Jacobs AL \& Carson DD 1993 Uterine epithelial cell secretion of interleukin-1 alpha induces prostaglandin $\mathrm{E}_{2}\left(\mathrm{PGE}_{2}\right)$ and $\mathrm{PGF}_{2}$ alpha secretion by uterine stromal cells in vitro. Endocrinology 132 300-308.

Johansson S \& Wide M 1994 Changes in the pattern of expression of alkaline phosphatase in the mouse uterus and placenta during gestation. Anatomy and Enbryology 190 287-296.

Jones CJ, Aplin JD, Mulholland J \& Glasser SR 1993 Patterns of sialylation in differentiating rat decidual cells as revealed by lectin histochemistry. Journal of Reproduction and Fertility 99 635-645.

Jones CJ, Kimber SJ, Illingworth I \& Aplin JD 1996 Decidual sialylation shows species-specific differences in the pregnant mouse and rat. Journal of Reproduction and Fertility 106 241-250.

Kennedy TG 1985 Evidence for the involvement of prostaglandins throughout the decidual cell reaction in the rat. Biology of Reproduction 33 140-146.

Kennedy TG 1986 Intrauterine infusion of prostaglandins and decidualization in rats with uteri differentially sensitized for the decidual cell reaction. Biology of Reproduction 34 327-335.

Kennedy TG \& Lukash LA 1982 Induction of decidualization in rats by the intrauterine infusion of prostaglandins. Biology of Reproduction 27 253-260.

Kennedy TG \& Doktorcik PE 1988 Effects of analogues of prostaglandin E2 and F2 alpha on the decidual cell reaction in the rat. Prostaglandins 35 207-219.

Kennedy TG \& Ross HE 1993 Effect of prostaglandin E2 on rate of decidualization in rats. Prostaglandins 46 243-250.

Kennedy TG \& Ross HE 1997 Temporal- and hormone-dependent changes in uterine sensitization for the decidual cell reaction and decidualization in vitro of rat endometrial stromal cells. Journal of Reproduction and Fertility 109 129-136.

Kennedy TG, Ross HE, Barbe GJ, Shu MA \& Zhang X 1998 Secretion of plasminogen activator by cultured rat endometrial stromal cells from uteri differentially sensitized for the decidual cell reaction. Molecular Reproduction and Development 49 268-276.

Kikuchi H, Sugiyama S \& Imajoh-Ohmi S 1995 A novel anti-apoptosis serum factor that down-regulates fas-mediated apoptosis. Journal of Biochemistry (Tokyo) 117 936-939.
Kimber SJ, Lindenberg S \& Lundblad A 1988 Distribution of some Gal beta 1-3(4)GlcNAc related carbohydrate antigens on the mouse uterine epithelium in relation to the peri-implantational period. Journal Reproduction and Immunology 12 297-313.

Kurita T, Lee K, Saunders PT, Cooke PS, Taylor JA, Lubahn DB, Zhao C, Makela S, Gustafsson JA, Dahiya R \& Cunha GR 2001 Regulation of progesterone receptors and decidualization in uterine stroma of the estrogen receptor-alpha knockout mouse. Biology of Reproduction 64 272-283.

Lim H \& Dey SK 1997 Prostaglandin E2 receptor subtype EP2 gene expression in the mouse uterus coincides with differentiation of the luminal epithelium for implantation. Endocrinology 138 4599-4606.

Lim H, Gupta RA, Ma WG, Paria BC, Moller DE, Morrow JD, DuBois RN, Trzaskos JM \& Dey SK 1999 Cyclo-oxygenase-2-derived prostacyclin mediates embryo implantation in the mouse via PPARdelta. Genes and Development 13 1561-1574.

Malaval L, Gupta AK \& Aubin JE 1995 Leukemia inhibitory factor inhibits osteogenic differentiation in rat calvaria cell cultures. Endocrinology 136 1411-1418.

McCormack SA \& Glasser SR 1980 Differential response of individual uterine cell types from immature rats treated with estradiol. Endocrinology 106 1634-1649.

Milligan SR, Cohen PE \& Finn CA 1995 The minimum requirements for oestradiol to induce uterine sensitivity for implantation and decidualization in mice. Human Reproduction 10 1502-1506

Monice FL, Andrade CG, Abrahamsohn PA, Soto-Suazo M, Oliveira SF \& Zorn TM 2001 Granulated decidual cells in the mouse deciduoma: a putative source of decidual prolactin in mice. Cells, Tissues, Organs 168 252-263.

Murdoch RN, Kay DJ \& Cross M 1978 Activity and subcellular distribution of mouse uterine alkaline phosphatase during pregnancy and pseudopregnancy. Journal of Reproduction and Fertility 54 293-300.

Ni H, Ding NZ, Harper MJ \& Yang ZM 2002a Expression of leukemia inhibitory factor receptor and gp130 in mouse uterus during early pregnancy. Molecular Reproduction and Development 63 143-150.

Ni H, Sun T, Ding NZ, Ma XH \& Yang ZM $2002 b$ Differential expression of microsomal prostaglandin e synthase at implantation sites and in decidual cells of mouse uterus. Biology of Reproduction 67 351-358.

O'Neill C 1985 Partial characterization of the embryo-derived platelet-activating factor in mice. Journal of Reproduction and Fertility 75 375-380.

Pakrasi PL 1997 Prostaglandins and ovum implantation in mice. Journal of Experimental Zoology 278 53-57.

Papay KD \& Kennedy TG 2000 Characterization of temporal and cell-specific changes in transcripts for prostaglandin E(2) receptors in pseudopregnant rat endometrium. Biology of Reproduction $\mathbf{6 2}$ $1515-1525$.

Paria BC, Ma W, Tan J, Raja S, Das SK, Dey SK \& Hogan BL 2001 Cellular and molecular responses of the uterus to embryo implantation can be elicited by locally applied growth factors. PNAS 98 1047-1052.

Pennica D, Shaw KJ, Swanson TA, Moore MW, Shelton DL, Zioncheck KA, Rosenthal A, Taga T, Paoni NF \& Wood WI 1995 Cardiotrophin-1. Biological activities and binding to the leukemia inhibitory factor receptor/gp130 signaling complex. Journal Biological Chemistry 270 10915-10922.

Pollard JW, Jahan M \& Butterworth PJ 1990 Characterization and expression of uterine and placental alkaline phosphatases in the mouse. Journal of Reproduction and Fertility 89 735-742.

Psychoyos A 1993 Uterine receptivity for egg-implantation and scanning electron microscopy. Acta Europaea Fertilitatis 24 41-42.

Rankin JC, Ledford BE, Jonsson HT, Jr. \& Baggett B 1979 Prostaglandins, indomethacin and the decidual cell reaction in the mouse uterus. Biology of Reproduction 20 399-404. 
Reese J, Brown N, Paria BC, Morrow J \& Dey SK 1999 COX-2 compensation in the uterus of COX-1 deficient mice during the pre-implantation period. Molecular and Cellular Endocrinology 150 23-31.

Sananes N, Baulieu EE \& Le Goascogne C 1976 Prostaglandin(s) as inductive factor of decidualization in the rat uterus. Molecular and Cellular Endocrinology 6 153-158.

Satyaswaroop PG, Bressler RS, de la Pena MM \& Gurpide E 1979 Isolation and culture of human endometrial glands. The Journal of Clinical Endocrinology and Metabolism 48 639-641.

Shen MM \& Leder P 1992 Leukemia inhibitory factor is expressed by the preimplantation uterus and selectively blocks primitive ectoderm formation in vitro. PNAS 89 8240-8244.

Shevinsky LH, Knowles BB, Damjanov I \& Solter D 1982 Monoclonal antibody to murine embryos defines a stage-specific embryonic antigen expressed on mouse embryos and human teratocarcinoma cells. Cell 30 697-705.

Siegfried JM, Nelson KG, Martin JL \& Kaufman DG 1984 Promotional effect of diethylstilbestrol on human endometrial stromal cells pretreated with a direct-acting carcinogen. Carcinogenesis 5 641-646.

Sisk MA, Lohmann CH, Cochran DL, Sylvia VL, Simpson JP, Dean DD, Boyan BD \& Schwartz Z 2001 Inhibition of cyclooxygenase by indomethacin modulates osteoblast response to titanium surface roughness in a time-dependent manner. Clinical Oral Implants Research 12 52-61.

Song H, Lim H, Das SK, Paria BC \& Dey SK 2000 Dysregulation of EGF family of growth factors and COX-2 in the uterus during the preattachment and attachment reactions of the blastocyst with the luminal epithelium correlates with implantation failure in LIF-deficient mice. Molecular Endocrinology 14 1147-1161.

Stewart CL \& Cullinan EB 1997 Preimplantation development of the mammalian embryo and its regulation by growth factors. Developmental Genetics 21 91-101.

Stewart CL, Kaspar P, Brunet LJ, Bhatt H, Gadi I, Kontgen F \& Abbondanzo SJ 1992 Blastocyst implantation depends on maternal expression of leukaemia inhibitory factor. Nature $\mathbf{3 5 9}$ 76-79.

Thiede MA, Yoon K, Golub EE, Noda M \& Rodan GA 1988 Structure and expression of rat osteosarcoma (ROS 17/2.8) alkaline phosphatase: product of a single copy gene. PNAS 85 319-323.

Ushikubi F, Segi E, Sugimoto Y, Murata T, Matsuoka T, Kobayashi T, Hizaki H, Tuboi K, Katsuyama M, Ichikawa A et al. 1998 Impaired febrile response in mice lacking the prostaglandin $\mathrm{E}$ receptor subtype EP3. Nature 395 281-284.

Vernallis AB, Hudson KR \& Heath JK 1997 An antagonist for the leukemia inhibitory factor receptor inhibits leukemia inhibitory factor, cardiotrophin-1, ciliary neurotrophic factor, and oncostatin M. Journal Biological Chemistry 272 26947-26952.

Weitlauf HM \& Suda-Hartman M 1988 Changes in secreted uterine proteins associated with embryo implantation in the mouse. Journal of Reproduction and Fertility 84 539-549.

Yang ZM, Le SP, Chen DB, Cota J, Siero V, Yasukawa K \& Harper MJ 1995 Leukemia inhibitory factor, LIF receptor, and gp130 in the mouse uterus during early pregnancy. Molecular Reproduction and Development 42 407-414.

Yang ZM, Das SK, Wang J, Sugimoto Y, Ichikawa A \& Dey SK 1997 Potential sites of prostaglandin actions in the periimplantation mouse uterus: differential expression and regulation of prostaglandin receptor genes. Biology of Reproduction 56 368-379.

Yee GM \& Kennedy TG 1991 Role of cyclic adenosine $3^{\prime}, 5^{\prime}$-monophosphate in mediating the effect of prostaglandin E2 on decidualization in vitro. Biology of Reproduction 45 163-171.

Ying Y \& Zhao GQ 2000 Detection of multiple bone morphogenetic protein messenger ribonucleic acids and their signal transducer, Smad1, during mouse decidualization. Biology of Reproduction 63 1781-1786.

Zhang X \& Croy BA 1996 Maintenance of decidual cell reaction by androgens in the mouse. Biology of Reproduction 55 519-524.

Received in final form 17 February 2004

Accepted 20 February 2004 